\title{
Janet Abu-Lughod and the World System: The History of World System Development and the Development of World System History
}

Barry K. Gills

University of Helsinki, Finland

Barry.Gills@helsinki.fi

Janet L. Abu-Lughod, in Before European Hegemony: The World System A.D. 1250-1350, made a remarkable contribution to scholarship, earning for this seminal work the status of a true classic. The intellectual influence and significance of this book was both pivotal and permanent, influencing the emergence and consolidation of post-Eurocentric perspectives of global history, which radically reinterpret the origins and historical development of the world system. What follows is a set of personal reflections on the intellectual context, arguments and framework of analysis put forward in this deservedly famous work.

\section{The Intellectual Context of Abu-Lughod's World System}

After completing a millennial history of Cairo (Abu-Lughod 1971) Abu-Lughod concluded that "...the Eurocentric view of the Dark Ages was ill-conceived. If the lights went out in Europe, they were certainly still shining brightly in the Middle East" (Abu-Lughod 1989, p. ix). She realized that Cairo "was only one apex in a highly developed system of urban civilization" (Abu-Lughod 1989: x). This insight led her to reconsider the role and character of medieval cities more generally, and to reject the Eurocentrism of Henri Pirenne and Max Weber and any hierarchically dichotomous analysis of (superior) Occidental versus (inferior) Oriental cities. She was also at "dis-ease" with Marx's treatment of the origins of capitalism. So when she came to read the first two volumes of Immanuel Wallerstein's path-breaking study The Modern World-System (Wallerstein 1974;1979), she came away with "a gnawing sense of Kuhnian anomaly, since they tended to treat the Europeandominated world system that formed in the long sixteenth century as if it had appeared de novo" (ibid, emphasis added). Her historical revisionism stemmed from a realization that there was "no part of the so-called 'Third World' in which the received wisdom of ethnocentric western scholarship not had been called into question by 'subalterns'... who find in their own histories not the stasis of tradition but the dynamics of orthogenic change, not the backwardeness vis-a'-vis the west assumed so off-handedly in much western scholarship, but the development of underdevelopment through subordination" (Abu-Lughod 1989:viii, emphasis added).

In 1984 she began her determined quest for answers. She was self-conscious of the magnitude of this task, knowing it was perilous scholarly ground. Most addressed various parts of the puzzle, whereas Abu-Lughod was explicitly attempting to "piece together in systematic fashion the connections among them" (Abu-Lughod 1989: xi), and construct an over-arching account of the world system "by looking at the connections between geographic entities that are usually treated by 
separate sets of specialists..." (ibid:ix). The breath of the sources which she proceeded to use in a remarkable three year period in the mid-1980s is testament to her excellence as a researcher ${ }^{1}$ and to the support of a circle of supportive scholars which included William H. McNeill, Immanuel Wallerstein, K.N. Chaudhuri, Andre Gunder Frank, and Charles Tilly, among many others.

The intellectual excitement surrounding her work began even before the book's publication in 1989. There was a significant exchange between Abu-Lughod and several scholars In Studies in Comparative International Development (22 (Winter) 1987-88). Abu-Lughod presented her outline of the world system in the thirteenth century, and Andre Gunder Frank, William H. McNeill, James M. Blaut, Alastair Taylor and Antony de Souza, responded. Upon the book's publication, Immanuel Wallerstein (1990) responded to Abu'Lughod's "Restructuring the Premodern World System" in his comments in Journal of World History (1990: 249-56). Andre Gunder Frank enthusiastically contributed to that dialogue in Journal of World History and elsewhere, and in voluminous personal correspondence with Abu-Lughod.

Frank regarded Abu-Lughod as a key figure who had, "in pushing the starting date for the world system back to 1250 " provided historical evidence and analysis that "cut into the gordian knot of the supposed break in world history at 1500" (1990). Frank's engagement with Abu-Lughod in 1987-88 had a very important impact on his future direction. He began to ask a new question: Does the World-System begin before 1500? Frank joined together with the present author in 1989 to begin collaborating on a series of articles to elaborate a new world system (without a hyphen) framework. ${ }^{2}$ We invited Abu-Lughod to a panel discussing her work, organized by the World Historical Systems Theory Group (within the International Studies Association), a new interdisciplinary circle of scholars analyzing long term and large scale patterns of social change in world history. ${ }^{3}$

Around the same time we invited her participation in a debate on world system analysis (Frank and Gills 1993), which included Wallerstein, Samir Amin, and David Wilkinson. There AbuLughod distinguished her position on issues of "discontinuity and persistence"; concerning the structural re-organization of world system(s); the role of regions as sub-systems in relation to the larger world system; her position on a "succession" of world systems (despite important continuities), and recapitulation of her argument that "The Fall of the East Precedes the Rise of the West". In this collection Abu-Lughod argues that Wallerstein tends "to overemphasize the discontinuity between the Eurocentred capitalist world economy that began to come into being then and the system of world-empires and world-economies that had preceded it" (Abu-Lughod 1993:278). Wallerstein denied that pre-sixteenth century patterns of world trade could be understood as a world(-)system.

\footnotetext{
${ }^{1}$ Abu-Lughod carefully engaged with previous scholarship in general medieval studies. Moreover, she consulted specialist works covering Europe (and country cases: France, Flanders, and Italy), the Mediterranean, The Middle East (including the Arab World), Asia (including India, Southeast Asia, the Strait of Malacca, and China).

${ }^{2}$ See for example, Gills and Frank (1990; 1991) Gills and Frank (1992), and Gills and Frank (1994; 2011) which were the foundations for this approach.

${ }^{3}$ The early core members of the World Historical Systems Theory Group included Christopher Chase-Dunn, Thomas D. Hall, Jonathan Friedman (and Kajsa Ekholm-Friedman), George Modelski, William R. Thompson, David Wilkinson, Robert A. Denemark, Stephen K. Sanderson, Sing C. Chew, Claudio Cioffi-Revilla, Alf Hornburg, Andrew Sherratt, Andre Gunder Frank and Barry K. Gills. The group's scope and ambition was towards a "unified study of world system history" through "transdisciplinary cooperation" (Denemark et. al, eds. 2000).
} 
In Before European Hegemony, Abu-Lughod had concluded that the $13^{\text {th }}$ century world system of international trade and production was substantially complex and sophisticated. This included "the technology of shipping and navigation, the social organization of production and marketing, and the institutional arrangements for conducting business, such as partnerships, mechanisms for pooling capital, and techniques for monetization and exchange" (Abu-Lughod 1989:353). Thus, "No simple, deterministic explanation" or one that focused on "special technological, cultural, psychological, or even economic characteristics of European society "could be sufficient, "since they tend to ignore the contextual changes in the preexistent system" (ibid). The $13^{\text {th }}$ century world system was characterized by co-existence and cooperation among several core regions and a variable set of cultural, social, religious, economic and political orders. However, "all seem to have permitted and indeed facilitated lively commerce, production, exchange, risk taking, and the like" (ibid, pp. 354-5). She is adamant that "the rise of the west was facilitated by the preexisting world economy it restructured." (ibid:361) It was above all European "trade-cumplunder" practices "that caused a basic transformation in the world system that had developed and persisted over some five centuries." (ibid)

Frank and Gills found much to agree with in Abu- Lughod's analysis. However, we emphasized continuities within one world system. Abu-Lughod at times seems to have sympathy with this position, but she added her own metaphor of "... a very long up-cycle with fluctuations that at times are so extreme that it is analytically useful to speak of 'breaks' and restructuring" (AbuLughod 1993:289). ${ }^{4}$ Both shared common ground in criticism of Wallerstein's Eurocentric analysis of the origins of the world system, on the continuous role of capitalist practices within it, and the early and sophisticated participation of the "east" in world system history. Both put great emphasis on continuities and persistence of certain structural features and long-term patterns. Both agreed that the restructuring of the world exchange nexus away from the (millennia old) centrality of the East Mediterranean-Central Asian- India axis, towards a trans-Atlantic orientation, and the formation of new global transoceanic exchange routes (largely under European control) was a pivotal restructuring in world system history.

Abu-Lughod offered a highly complex and stimulating approach to "unevenness" and the interaction of various "cycles" within the world system. Her empirical mapping of diverse economic and political cycles lead her to conclude that "given this variability" scholars should not reify cycles (or regard Kondratieff waves' 45-50 years) "as if they were forces in their own right" (Abu-Lughod 1989:356). "Rather, the theory we have been setting forth suggests that when there was a period of congruence among the upward cycles of related regions, these cycles moved synergistically" (ibid: 358-9). The linkages to the world system and their feedback effects "intensified local development," and "the same was true in reverse," i.e. whereby "declines in one (region or circuit) inevitably

\footnotetext{
${ }^{4}$ The rest of the passage reads: "There is, then, no necessary contradiction between seeing the persistence and even improvement in economic activities over time within a given region and seeing that this region was falling increasingly below the average change for the system or the exponentially increasing shift in a region that, due to restructuring, was far outdistancing the subregion in question." She concluded, "I urge study of not only the continuities at the subsystem level, but also the discontinuities most evident at large scale" (1993:289).

${ }^{5}$ For a further critique of Eurocentric history and re-writing of world system history from a non-Euro-centric perspective, see Gunder Frank (1998). For Frank's final work of world system history, See Andre Gunder Frank (2014) ReOrienting the 19th Century: Global Economy in the Continuing Asian Age.
} 
contributed to declines elsewhere" precisely due to these linkages, and particularly in "contiguous parts that formed "trading partnerships"" (Abu-Lughod 1989:359).

\section{Abu-Lughod's theory of (world) systemic change}

Abu-Lughod did much more than provide an empirical mapping of the production and exchange nexus of the medieval world system. She offers us an extremely rich and distinctive theory of systemic change. I will discuss the five main elements of this theory.

1. On the analytical centrality of "connections" in systemic change. She argues that contra the view that "independent" variables, such as "national character," affect "dependent" ones, "systemic changes should rather be viewed as shifts in the direction and configuration of central trends (or vectors)." "Such vectoral outcomes result from the cumulative effect of multiple shifts in smaller vectors, some of which are independent of one another but many of which derive from interrelated or systemic causes. In a system, it is the connections between the parts that must be studied. When these strengthen and reticulate, the system may be said to 'rise,' when they fray, the system declines, although it may later undergo reorganization and revitalization" (Abu-Lughod 1989:368, emphasis added).

2. On the succession of world systems in relation to cumulative aspects of reorganization: She argues that "...successive systems reorganize in a somewhat cumulative fashion, the lines and connections laid down in prior epochs tending to persist even though their significance and roles in the new system may be altered. Given cumulative technological change, which offers at least the potential to increase the range and speed of interactions, systems tend to expand and become more integrated unless major catastrophes interfere" (1989:368, emphasis added). She tends to vary the emphasis between continuity within a world system, and discontinuity between distinct configurations and successive world systems. She emphasizes that "restructuring, rather than substitution, is what happens when world systems succeed one another, albeit after intervening periods of disorganization" (1989:366). The "failure" of a world system refers more to the "declining efficacy and functioning of the ways in which they (the parts or regions) were formerly connected," so that when a world system "devolves," "[i]ts devolution was both caused by and a sign of the 'decline' of its constituent parts, with multiple feedback loops" (ibid pp. 366-7). Perhaps the most cogent passage on this topic is that on "rise and fall." Her elegant and powerful formulation deserves quotation:

In the course of history, some nations, or at least groups within them, have gained relative power vis-a -vis others and have occasionally succeeded in setting the terms of their interactions with subordinates, whether by means of direct rule (empires), indirect supervision (what we today term neocolonialism), or through unequal influence on the internal policies of others (hegemony). When this happens, it is called a 'rise'. Conversely, the loss of an advantageous position is referred to as a 'decline,' even if there is no real deterioration in absolute level of life... World systems do not rise and fall in the same way that nations, empires, or civilizations do. Rather, they rise when integration increases and they decline when connections along older pathways decay...the old parts live on and become the 
materials out of which restructuring develops...such restructuring is said to occur when players who were formerly peripheral begin to occupy more powerful positions in the system and when geographic zones formerly marginal to intense interactions become foci and even control centers of such interchanges (1989:367, emphasis original).

3. On the historical limits of world system integration, and hegemony: She argues that "no system is fully integrated" and "therefore none can be completely controlled, even by the most powerful participants" (Abu-Lughod 1989:368-9). Power over the system is also limited, and never complete - in particular the power to control or prevent systemic change itself. She makes an important argument concerning how sub-systems, regional configurations, or even "small localized conditions" could interact with adjacent conditions "to create outcomes that might not otherwise have occurred, and large disturbances sometimes flutter to an end while minor ones may occasionally amplify wildly, depending on what is happening in the rest of the system" (ibid:369). This reflects her non-deterministic post-positivist perspective on social science knowledge. The whole may be greater than the sum of the parts, but sometimes the parts can alter the whole in dramatic unpredicted fashion.

4. On causality and social change in relation to world system(s): She argues "changes have causes but only in context. The very same acts have different consequences when they occur at different times and when the surrounding system is structured differently" (ibid). She rejects extremes of structuralism and reductionist thinking, implying an alternative methodology which recognizes complex conditioned contingency, and advocating a historically "open" approach to understanding causality in social change.

5. On "Rise and Decline" in World System(s): She argues that "...a theory of systemic change should be able to account for system decay as well as system growth" (ibid, emphasis added). Here, Abu-Lughod seeks an alternative to simplistic linear and cyclical perspectives. Her approach investigates both long term "development, expansion, and greater connectivity of a system," (i.e. increases in "systemness"), and recurrent retrogressive historical tendencies, i.e. patterns of "decline" or "decay" (see point 2 above). Abu-Lughod admonishes scholars to study both modalities of long term large scale social change.

\section{“Gaps" in Abu-Lughod's Analysis of the World System}

No work of such ambitious scope could be fully holistic and comprehensive. Thus, there are gaps in Abu-Lughod's analysis. She omits the Baltic from her eight circuit schema. ${ }^{6}$ The Baltic circuit was existing during the so-called "Viking" era, and continued during the Hanseatic league of cities. She omits the Baltic/Dnieper-Volga/Black \& Caspian Seas circuit, which is recorded by Arab and Islamic travelers' accounts from the Medieval period. ${ }^{7}$ She also omits the West African- trans-Saharan-

\footnotetext{
${ }^{6}$ The map of Abu-Lughod's schema of the eight circuits in the thirteenth century world system appears on p. 34 of Before European hegemony, and is reproduced on p. 283 in Frank and Gills (1993).

${ }^{7}$ See: Ibn Fadlan: Ibn Fadlan and the land of darkness: Arab Travelers in the Far North, (Lunde and Stone 2012), which includes detailed maps of the circuit, which linked Baltic Europe, northern Russia, and Islamic metropoles including Baghdad, Cairo, and Central Asian cities. Boris Kagarlitsky's world system history of Russia (Kagarlitsky 2008) analyses the role of this circuit on the development of cities and states in the formative period of Russian history.
} 
Mediterranean circuit, though this exchange nexus played a key role in formation of West African cities and states of the medieval period. Her Indian Ocean circuit (VI) could have been extended on the African coast to include Kilwa, Sofala, and Mauritius. Her circuit VIII, East and Southeast Asia, could have been extended to encompass the Korean peninsula and Japan. The inclusion of these circuits would have provided a more comprehensive analysis of the "Afro-Eurasian world system" of the medieval period.

Finally, in terms of theoretical gaps, Abu-Lughod offers no sustained analysis of "liberation" or "emancipation," eschewing Marxist historiographical attention to class conflict and any telos towards emancipation or "socialism." She argues that the state often played an active or key role in organizing and facilitating private capitalists in the pursuit of the accumulation of capital. However, she stops short of offering us a systematic analysis of this relationship. She does much more to contribute to the controversy over the role of capitalists and merchants. Her rich textual sources were deployed to convincingly argue the case for the continuingly influential role of "capitalist" or "bourgeois" classes (and perhaps even for a "medieval capitalism" in some regions) throughout medieval world system history. She succeeded in offering a fresh analysis of the continuous central role of "an archipelago of "world cities" (Abu-Lughod 1989:353) in shaping world system history. Thus, Abu-Lughod's magisterial analysis in Before European Hegemony added considerable force and authority to overturn traditional "feudalist" interpretations of medieval history, as well as to invigorate a new generation of scholarship that seeks a unified study of world (system) history and is enriched by transdisciplinarity. This impetus continues to profoundly influence scholarship to the present day, as post-Eurocentric and increasingly "holistic" perspectives on global history become "normal" along with implicit "world system" perspectives on the indispensable importance of seeing "connections" that have shaped human experience for millennia until the present. Abu-Lughod's framework of analysis of the world system, and her theory of systemic change, are equally relevant to understanding contemporary restructuring of the world system as to the history of past millennia.

\section{Extricating the Analytics: Janet Abu-Lughod's Before European Hegemony}

Saskia Sassen

Columbia University

www.saskiasassen.com

Armed with her strong ideas and desire to discover, rather than merely replicate, Janet Abu-Lughod was fearless in launching new interpretations about complex conditions. She saw no problem in developing critical analyses of the work of those she considered her friends, albeit in some AbuLughodian version of friendship. Over the decades, walking on ground strewn with her devastating critiques, Janet was always already focused on her next project.

All these features are present in her major contribution to world-system analysis, the much admired and controversial Before European Hegemony: The World System A.D. 1250-1350. It took 
enormous work and courage to engage this subject. And it took seeing the complex shape of a historical possibility: a "world system" in a pre-European era -- the period A.D. 1250-1350 — where Europe was merely one component. In this project Abu-Lughod both criticized and expanded Wallerstein's seminal The Modern World System. Janet was critical of what she saw as the Europecentered bases and histories from which Wallerstein developed the analytic tools underlying his theorizing of a world-system. Abu-Lughod argues that the modern European "world system" is, in large measure the inheritor and continuator of an antecedent, a "world system" centered on the Asia of the Moguls.

Her theoretical framework is anchored in financial and commercial networks within and between the main zones she sees in her "world system": Europe, the Eastern Mediterranean, the Persian Gulf and western Indian Ocean, the eastern Indian Ocean and Southeast Asia, and China. Empirically much of the focus is on major trading centers. So began the massive work of studying and sorting out vast literatures. The result was a masterful and often controversial account about a multimodal, distributed world-system. Janet's construction of this world-system is hers, even as each part of this world-system is the subject of much scholarly work.

Indeed, much of this scholarship has covered several centuries before her 1250-1350 focus and generally finds that the great commercial and trading periods for many of the components of this world system had happened earlier. However, what Janet emphasized is the articulation of these various components and thereby the possibility of a world-system. Prosperity and rising economic capacity was not enough for Janet's analysis. What she was after was the existence of networks connecting these diverse components and the modalities of such connections. This led her to focus on more than simply periods of maximum prosperity, as some of her critics argued she should have. In her interpretation of the evidence, the networks connecting the diverse parts of this system came later, often after the periods of highest growth. This explains why, for Janet, maximum prosperity or growth was not necessarily the defining factor.

What was particularly important for Janet's analysis was that Europe became part of that world system: one dominated by the Moguls, not by Europe! The interconnections among various parts of Asia had been in some cases stronger a century or so before 1250 . And while it had included some parts of Europe, notably Spain, the core elements of that world system were far from Europe. In Janet's world system, it was the rise of the Moguls in the $13^{\text {th }}$ century and onwards that were the dominant glue. Further, what mattered in her analysis was that they supported trans-Asian caravan trading, which in turn led to networks that enabled Europe's incorporation into a larger space of Eurasian commerce. This analysis both brought Europe into a vast Asian geography dominated by the Moguls and sought to show that, whatever the conditions explaining the rise of the later European world-system of the $16^{\text {th }}$ century onwards, these conditions were not the only ones that could lead to a world-system.

Yet another major contribution of the research in Before European Hegemony is Janet's focus on the structural architecture of world-systems. The existence of a complex Asia-centered territorial formation long before the European world-system offered an opportunity for comparing this structural aspect. It was especially so because it was as yet unexamined through the lenses of worldsystems analysis - though much studied by diverse specialized disciplines which in fact made Janet's examination possible. What matters most, perhaps, is that this literature allowed her to establish significant structural differences between that earlier Asian world system of the 1200 s and the 
European one that took off in the $1500 \mathrm{~s}$. What she found, even if controversial among historians, was that the Asian system was marked by a sort of balanced interdependence. This was a major contrast with the familiar developmental and spatial hierarchy of the European system under capitalist hegemony.

This then also led Janet to yet another important insight, already mentioned above: The conditions internal to Europe that are generally considered to have enabled the emergence of the European world-system were not the only ones to enable world-system formation. Other, nonEuropean types of conditions could also enable this process. There was no historical necessity explaining the outcome of European domination over much of the planet. Even more, some of the technical advances that enabled the European trajectory came from the East, from that earlier, Asiacentered world-system. Janet also saw in this the fact that it was not European superiority that brought down the Asia-centered system: the latter degraded due to its own specific conditions long before Europe's rise. Rather, what might be more likely is that the fall of the Asia-centered system enabled the later rise of a Europe-centered system. It cleared the imperial space, so to speak.

I would so much like to have a long conversation with Janet and ruminate with her about the emergent formations, possibly world systems, that I detect today in our world. The fact that she had the courage and did all this work to establish the existence of an earlier world-system with its own specific dynamics and conditionalities, makes me think she would at least be open to some of what I see.

I see yet another structural architecture in the making today. It is neither similar to the Asian nor the European. Neither is it quite Arrighi's rise of a hegemonic China examined in his masterful The Long Twentieth Century. Very briefly, I see a disassembling of older, bounded formations, particularly of nation-states, but also of the ongoing de facto (even if not de jure) imperial dominations. While interstate borders are pretty stable, the emergent geographies that mark our epoch give us a very different shape. We see the making of economic and power spaces that cut across those boundaries and encompass only part of nation-states. Further, these geographies cut across many of the old divides, notably North-South and East-West. They incorporate elites and elite projects in all these diverse zones and discard much of the rest --in the Global South especially, but now increasingly also in the Global North. They are partial assemblages of pieces of existing national territories and are predicated on a growing range of expulsions of the people, places, and operations that do not fit the new mode. While these expulsions may have been especially sharp in the Global South, now they are also increasingly happening in the Global North. Further, these emergent geographies cut across multiple divisions: for instance, the United States is a great host of global finance, but so is China. What matters more to our understanding of today's world? Is it that the political systems of these two countries are very different or that both increasingly financialize their economies? These new geographies are brutal, even if often complex and constituted through forms of knowledge we admire and respect -such as the algorithms so central to finance or the complex logistics of outsourcing jobs. It may well be a kind of new world-system, but one not centered in the old familiar distinctions. 
182 Journal of World-Systems Research

\title{
Remembering Janet Abu-Lughod
}

\author{
Immanuel Wallerstein \\ Yale University \\ immanuel.wallerstein $Q$ yale.edu
}

Janet Abu-Lughod was a remarkable scholar and bequeathed a significant legacy to the historical social sciences. The first thing to remember is that her initial and continuing interest and identity was as a student of urban life, a subject to which her early reading of Lewis Mumford turned her. However, before she moved to Cairo with her husband Ibrahim Abu-Lughod, her life experience had been almost entirely within the United States. Going to Cairo changed and deepened her perspective about the world.

Janet was someone who wanted to learn from the world in which she lived. And living in Cairo was very different. She became engrossed in the urban life of Cairo. And she came to see urban life with different spectacles. Her first major work, published in 1971, was Cairo: 1001 Years of the City Victorious. From there, it was only a short step to viewing Egyptian culture as it related to all the other cultures of the world. Egypt was not however just any non-U.S. (or non-"western" country to observe. Egypt had arguably one of the two longest-continuous historical legacies in the world, competing in this sense only with China. Studying Egypt empathetically had to mean immersing ourselves in a long-term historical perspective, something she had already recognized in writing her book about Cairo.

This turn to studying Egypt in relation to the rest of the world was the prelude to her intellectual journey that was to produce the book that made her famous, Before European Hegemony: The World System A.D. 1250-1350. One should note two things about this title. It starts with the word "before." Janet intended her book to be one combatting Eurocentrism and any notion that the key to European triumph in the modern world-system had its roots in some special cultural characteristics of western Europe.

The second thing to note about the title is the time limitation. The book was not intended to be an exposition of world history over 5000 or 10,000 years. It focused on what she thought was a key period of prelude to the "rise of the west." Her method essentially was to demonstrate that there was a world system composed of a number of overlapping circles, somewhat equivalent in their political economies. Precisely because these circles overlapped, she could demonstrate the practical links between them, both of economic and political interconnections and of cultural diffusions.

I remember discussing this project with her at its beginning and through its later stages. She was in constant search of persons to whom to talk and books to read. She sought to learn, to elucidate, to integrate, and to conclude. The reason the book had so much impact is not because everyone agreed with it - in whole or in part - but because it forced just about everyone to face up to issues over which they had previously glided too facilely.

As many have observed, she continued to pursue her concern with urban realities - in many different locales. But her second major contribution in my view was one that many of her memorialists do not even mention. It happens to be one in which I was involved. When I was 
president of the International Sociological Association(1994-1998), I engaged the IS A in sponsoring a series of small regional conferences. The objective was to get scholars of a region to reflect on their social realities and their social sciences. These regional meetings of up to 30 persons always included two to three persons from outside the region, in order to keep the reflection from being excessively introverted. IS A published their results.

It turned out to be relatively easy to find appropriate convenors for such meetings in most of the world. The trickiest region in which to do this properly was North America (the United States and Canada). As I thought about the innumerable prominent sociologists of the region, it seemed to me that Janet was the ideal convenor. She knew the United States and its sociology well. But she also had genuine interest in and concern with the rest of the world and had demonstrated that in her own scholarship.

I offered this role to Janet. Initially, she said sorry, but she had no time. But a week or so later, she wrote me and said that she hadn't considered what a gift I was offering her. She agreed to do it, enthusiastically. And she did it remarkably well. The final result appeared in a reduced version published by the ISA, reduced because it had to meet ISA's size limitation for these books. The title was Millennial Milestone: The Heritage and Future of Sociology in the North American Region.

For those who haven't read it, I recommend very strongly looking at her introduction to the book, "The Heritage and Future of Sociology." In this introduction she spelled out not only a very pertinent analysis of the historical origins of North American sociology and the reasons for its special characteristics, but also an agenda for the future with which we still need to come to terms. We do not always necessarily recognize that the turn that at least some sociologists have taken was in important ways inspired by Janet. But being forgotten in this way is a sure sign of success. Janet's proposals have become common wisdom. And, as she herself would surely have said, let us go forward from here.

\section{References}

Abu-Lughod, Janet L. 1971. Cairo: 1001 years of the City Victorious, Princeton: Princeton University Press.

1987-88. "The Shape of the World System in the Thirteenth Century," Studies in Comparative International Development 22 (Winter): 3-53.

1989. Before European Hegemony: The World System A.D. 1250-1350, new York and Oxford, Oxford University Press.

. 1999. "The Heritage and Future of Sociology." Pp. 9-22 in Millennial Milestone: The Heritage and Future of Sociology in the North American Region, Vol. 7 Social Knowledge: Heritage, Challenges, Perspectives. International Sociological Association.

1990. "Restructuring the Premodern World System", Review 8 (Spring): 273-85.

1993. "Discontinuities and Persistence: One world system or a succession of systems? pp. 278-291, in Andre Gunder Frank and Barry K. Gills (eds). 1993, The World System: five hundred years or five thousand?, London and New York: Routledge.

1999. New York, Chicago, Los Angeles: America's Global Cities. Minneapolis:

University of Minnesota Press. 
Boles, Elson E. 2012. "Assessing the Debate between Abu-Lughod and Wallerstein over the Thirteenth-Century Origins of the Modern World-System."Pp. 21-29 in S. J. Babones and C. Chase-Dunn (eds.) Routledge Handbook of World-Systems Analysis. New York: Routledge.

Chase-Dunn, C. and Andrew K. Jorgenson, "Regions and Interaction Networks: an institutional materialist perspective," 2003 International Journal of Comparative Sociology 44,1:433450.

Denemark, Robert A., Jonathan Friedman, Barry K. Gills, and George Modelski (eds) World System History: The Social Science of Long-Term Change, London and New York: Routledge.

Frank, Andre Gunder. 1998, ReOrient: Global Economy in the Asian Age, Berkeley, Los Angeles, London: University of California Press.

.2014. ReOrienting the 19th Century: Global Economy in the Continuing Asian Age. Edited with an Introduction by Robert A. Denemark, Afterword by Barry K. Gills, Boulder: Paradigm Publishers.

Frank, Andre Gunder and Barry K. Gills (eds). 1993, The World System: five hundred years or five thousand? London and New York: Routledge.

Gills, Barry K. and Andre Gunder Frank. 1990, "The Cumulation of Accumulation: Theses and Research Agenda for 5000 Years of World System History." Dialectical Anthropology 15 (1): 19-42. An expanded version was published as "5000 Years of World System History: the Cumulation of Accumulation" Pp. 67-111 in Precapitalist Core Periphery Relations edited by Christopher Chase-Dunn and Thomas Hall. Boulder, CO: Westview press (1991).

. 1992, "World System Cycles, Crises, and Hegemonial shifts 1700 BC to 1700 AD." Review 15 (4) (fall): 621-87.

. 1994/2011. "The Modern World System under Asian Hegemony: the Silver Standard World Economy 1450-1750." Pp. 50-80 in Andre Gunder Frank and Global development: Visions, remembrances, and explorations, Patrick Manning and Barry K. Gills (eds). London and New York: Routledge.

Kagarlitsky, Boris. 2008. Empire of the Periphery: Russia and the World System. Translated by Renfrey Clarke, London and Ann Arbor, MI: Pluto Press.

Lenski, Gerhard. 2005. Ecological-Evolutionary Theory. Boulder, CO: Paradigm Publishers.

Lunde, Paul and Caroline Stone. 2012. Ibn Fadlan and the Land of Darkness: Arab Travellers in the Far North, translated and with an Introduction by Paul Lunde and Caroline Stone, London: Penguin Books.

Modelski, George. 2003. World cities: -3000 to 2000. Washington, DC: FAROS2000.

Wallerstein, Immanuel 2011 [1974] The Modern World-System I: Capitalist Agriculture and the Origins of the European World-Economy in the Sixteenth Century. Berkeley: University of California Press. . 1979, The Modern World System II. New York: Academic Press. 1990, Journal of World History, 1 (2) Fall: 249-56.

Wilkinson, David. 1987. "Central Civilization" Comparative Civilizations Review 17:31-59 (Fall). 